\title{
Effect of viscosity on digestion of nutrients in conventional and germ-free chicks
}

\author{
D. J. Langhout ${ }^{1}$, J. B. Schutte ${ }^{1}$, J. de Jong ${ }^{1}$, H. Sloetjes ${ }^{2}$, M. W. A. Verstegen ${ }^{3}$ and S. Tamminga ${ }^{3}$ \\ ${ }^{1}$ TNO Nutrition and Food Research Institute, Department of Animal Nutrition and Physiology (ILOB), PO Box 15, \\ 6700 AA Wageningen, The Netherlands \\ ${ }^{2}$ Institute for Animal Science and Health (ID-DLO), PO Box 65, 8200 AB Lelystad, The Netherlands \\ ${ }^{3}$ Department of Animal Nutrition, Wageningen Agricultural University, PO Box 338, 6700 AH Wageningen, \\ The Netherlands \\ (Received 13 January 1999 - Revised 27 August 1999 - Accepted 6 October 1999)
}

\begin{abstract}
A study was conducted with conventional and germ-free broiler chicks to obtain more information on the role of the intestinal microflora in the anti-nutritive effects of NSP in broiler chicks. As the NSP source, highly methylated citrus pectin (HMC) was used at a dose level of $30 \mathrm{~g} / \mathrm{kg}$ in a maize-based diet. The diets fed to the germ-free chicks were $\gamma$-irradiated, whereas those fed to the conventional chicks were not. Feeding the HMC diet to conventional birds depressed weight gain and food utilization $(P<0 \cdot 05)$, whereas in germ-free birds only weight gain was reduced $(P<0 \cdot 05)$. Feeding the HMC diet to conventional birds reduced digestibilities of energy and starch at the end of the jejunum. Ileal digestibilities of starch and energy were not strongly affected when birds were fed on the HMC-containing diet. Faecal digestibilities of organic matter, crude fat, starch and amino acids, $\mathrm{N}$ retention and metabolizable energy were reduced when conventional chicks were fed on the HMC diet. Feeding the HMC diet to germ-free birds hardly affected faecal digestibility of nutrients and $\mathrm{N}$ retention, whereas metabolizable energy was increased. Feeding the HMC diet to conventional or germ-free birds increased the viscosity of the digesta in the small intestine. This increase in digesta viscosity was more pronounced in conventional than in germ-free birds. The $\mathrm{pH}$ of ileal digesta was reduced when HMC was added to the diet of conventional chicks, but not in germ-free chicks. Feeding the HMC diet to conventional birds markedly affected morphology of the gut wall, whereas in germ-free chicks very little effect was found on gut morphology. Based on the results of the present study, it is concluded that the gastrointestinal microflora mediates the magnitude of the anti-nutritive effects of HMC in broiler chicks. However, the exact role of the microflora in chicks in the magnitude of the anti-nutritional effects of HMC could not be derived from the present study, since the results might have been influenced by $\gamma$-irradiation of the diets fed to the germ-free chicks.
\end{abstract}

Intestinal microflora: Citrus pectin: Germ-free broiler chicks

Water-soluble NSP such as pentosans in wheat and rye are held responsible for the reduction in performance of and nutrient digestibility by broiler chicks (White et al. 1981; Fengler \& Marquardt, 1988; Choct \& Annison, 1990, 1992). The mechanism by which these NSP fractions exert their anti-nutritive activities is still not well understood. It is assumed that an increase in viscosity of the aqueous fraction, as a result of their viscous properties, is the primary mechanism by which these water-soluble NSP reduce nutrient digestibility (Fengler \& Marquardt, 1988; Choct \& Annison, 1992). An increase in viscosity of digesta may limit mixing of nutrients with pancreatic enzymes and bile acids (Edwards et al. 1988). Moreover, movement of nutrients towards the gastrointestinal wall is reduced by an increase in digesta viscosity, which consequently limits digestion and absorption (Antoniou et al. 1981; Fengler \& Marquardt, 1988).

A second means by which water-soluble NSP may reduce performance of chicks has also been discussed, namely that the viscous character of water-soluble NSP is directly to blame only for the anti-nutritional effects of watersoluble NSP, and the excessive stimulation of the intestinal

\footnotetext{
Abbreviations: HMC, highly methylated citrus pectin; ME, metabolizable energy; VFA, volatile fatty acids.

* Corresponding author: Dr D. J. Langhout, present address Provimi BV, PO Box 5063, 3008 AB Rotterdam, The Netherlands, fax +31 10 485 0297 , email langhout@provimi.com
} 
microflora is the direct causative agent (Campbell et al. 1983b). An increase in microbial activity in the intestinal tract increases deconjugation of bile acids in the small intestine as shown by Langhout et al. (1999). This reduction in conjugated bile acids was suggested to reduce the formation of micelles, which may limit absorption of fatty acids (Coates et al. 1981). Since long-chain saturated fatty acids in free form are absorbed in very small quantities (Garrett \& Young, 1975), a greatly reduced rate of fat absorption would occur in chicks fed on tallow-containing diets as a result of an increase in intestinal microbial activity. This is supported by the results of Antoniou \& Marquardt (1982), Ward \& Marquardt (1983) and Langhout et al. (1999). These investigators found that the anti-nutritive effects of viscous water-soluble NSP were more pronounced when tallow was included in the diet than when the fat source was soyabean oil. These results indicate also that, in addition to viscosity, the intestinal microflora influenced the magnitude of the anti-nutritive effects of water-soluble NSP in broiler chicks.

The present study was undertaken to obtain more information on the role of the intestinal microflora in the anti-nutritive properties of water-soluble NSP by using conventional and germ-free broiler chicks. The water-soluble NSP-containing product involved in the study was highly methylated citrus pectin (HMC).

\section{Materials and methods}

\section{Diets}

The composition of the basal diet is presented in Table 1 . The basal diet was formulated to meet the requirements of broiler chicks (National Research Council, 1994). Additives such as antibiotics or coccidiostats were omitted from the diets, as they may interfere with microbial activity. HMC (type CU 301, 30 mg/kg, methylation $>65 \%$; Contined, Bennekom, The Netherlands) was added to the maize-based diet. The pectin product, which was supplied as anhydrous polysaccharide, was substituted in the diet by weight for Diamol (5 g/kg), an insoluble ash (Franz Bertram, Hamburg, Germany) and tapioca $(25 \mathrm{~g} / \mathrm{kg})$. The metabolizable energy (ME) value for both HMC and Diamol was assumed to be zero.

\section{Animals}

In the trial with conventional birds, 1-d-old male broiler chicks ('Ross') were used, which were housed in two-tiered, electrically heated battery cages having wire floors with a floor space of $0.975 \mathrm{~m}^{2}$. The cages were located in an insulated room of controlled temperature and humidity. Chicks were subjected to continuous artificial fluorescent illumination. Each treatment was allotted at random to eight cages with twenty-four birds each. The experimental diets were fed for $21 \mathrm{~d}(1-21 \mathrm{~d}$ of age). Chicks were weighed individually and food consumption for each cage was recorded at the end of the trial. Water intake was measured for each cage separately at intervals of $12 \mathrm{~h}$ for $4 \mathrm{~d}(15-19 \mathrm{~d}$ of age) as the difference between a predetermined volume of water in the trough and the volume remaining in the trough. Water intake was not corrected for possible evaporative
Table 1. Composition of the basal (maize-based) diet $(\mathrm{g} / \mathrm{kg})$

\begin{tabular}{|c|c|}
\hline Ingredient & $\mathrm{g} / \mathrm{kg}$ \\
\hline Maize & $500 \cdot 0$ \\
\hline Tapioca & $27 \cdot 0$ \\
\hline Soyabean oil & $25 \cdot 0$ \\
\hline Animal fat & $60 \cdot 0$ \\
\hline Soyabean meal (500 g crude protein $/ \mathrm{kg}$ ) & $256 \cdot 0$ \\
\hline Casein & $63 \cdot 0$ \\
\hline Fish meal & 20.4 \\
\hline Diamol & $5 \cdot 0$ \\
\hline Limestone & $13 \cdot 3$ \\
\hline $\mathrm{Ca}\left(\mathrm{H}_{2} \mathrm{PO}_{4}\right)_{2}$ & $13 \cdot 4$ \\
\hline Salt & $2 \cdot 3$ \\
\hline Vitamins + minerals mixture* & $10 \cdot 0$ \\
\hline $\mathrm{NaHCO}_{3}$ & 1.8 \\
\hline $\mathrm{KHCO}_{3}$ & 1.6 \\
\hline DL-Methionine & $1 \cdot 2$ \\
\hline \multicolumn{2}{|l|}{ Contents: } \\
\hline DM (analysed) & 893 \\
\hline Crude protein (analysed) & 228 \\
\hline Crude fat (analysed) & 98 \\
\hline Ash (analysed) & 72 \\
\hline Starch (analysed) & 326 \\
\hline Metabolizable energy (calculated, MJ/kg) $\dagger$ & $12 \cdot 8$ \\
\hline Ca (calculated) & 8.7 \\
\hline P (calculated) & $7 \cdot 0$ \\
\hline Lysine (analysed) & 13.8 \\
\hline Methionine + cystine (analysed) & $9 \cdot 0$ \\
\hline
\end{tabular}

* Supplied (/kg diet): riboflavin $4 \mathrm{mg}$; nicotinamide $40 \mathrm{mg}$; D-pantothenic acid $12 \mathrm{mg}$; choline chloride $500 \mathrm{mg}$; cyanocobalamin $15 \mu \mathrm{g}$; DL- $\alpha$-tocopheryl acetate $20 \mathrm{mg}$; menadione $5 \mathrm{mg}$; retinyl acetate $3.44 \mathrm{mg}$; cholecalciferol $50 \mathrm{mg}$; biotin $0.1 \mathrm{mg}$; folic acid $0.75 \mathrm{mg}$; $\mathrm{FeSO}_{4} .7 \mathrm{H}_{2} \mathrm{O} 300 \mathrm{mg} ; \mathrm{MnO}_{2}$ $100 \mathrm{mg} ; \mathrm{CuSO}_{4} .5 \mathrm{H}_{2} \mathrm{O} 100 \mathrm{mg} ; \mathrm{ZnSO}_{4} . \mathrm{H}_{2} \mathrm{O} 150 \mathrm{mg} ; \mathrm{Na}_{2} \mathrm{SeO}_{3} .5 \mathrm{H}_{2} \mathrm{O}$ $0.15 \mathrm{mg}$; KI $5 \mathrm{mg}$; $\mathrm{CoSO}_{4} .7 \mathrm{H}_{2} \mathrm{O} 1 \mathrm{mg}$ and antioxidant (ethoxyquin) $100 \mathrm{mg}$. $\uparrow$ Calculated from the data provided by the Dutch Bureau of Livestock Feedingstuffs (1994).

losses. The diets (as pellets) were fed ad libitum. Water was available ad libitum via an automatic device.

The trial with germ-free chicks consisted of two subtrials. Each sub-trial was carried out under similar conditions. Naturally clean 18-d-old brood eggs of a normal broiler strain ('Ross') were incubated, sterilized with formaldehyde $(370 \mathrm{ml} / \mathrm{l})$ for $20 \mathrm{~min}$, injected with $0.33 \mathrm{ml}$ Exenal per egg (natrium ceftiofur; Upjohn, Kalamazoo, MI, USA) and hatched in a pre-isolator equipped with thermostatically controlled supplementary heat sources. In each sub-trial, $2 \mathrm{~d}$ after hatching birds were sexed and transferred to one of the four isolators. To each isolator five female and five male chicks were allotted such that the average weight of the birds in each isolator was similar $(77 \mathrm{~g})$. Thus, in total the study involved four isolators with five female and five male birds each per treatment. The isolators as well as the materials entering or leaving the isolator were sterilized with a formaldehyde $(370 \mathrm{ml} / \mathrm{l})$ spray. All diets were sealed in plastic bags and sterilized by irradiation at $2 \mathrm{Mrad}$ (Gammaster, Ede, Netherlands). Feed (as pellets) and water were available ad libitum. Birds were fed on the basal diet before they were transferred to the isolators. The germ-free status of these chicks was verified by means of microscopic examination of Gram-stained faecal smears and microbial culture of excreta samples. In the first sub-trial, birds were not contaminated with any bacteria in the intestinal tract. In the second sub-trial, birds 
were contaminated to some extent with Bacillus lichenifermis. To minimize growth of $B$. lichenifermis drinking water was medicated with $4 \mathrm{ml} / 1$ Methoxasol-T (trimethoprim $20 \mathrm{mg} / \mathrm{ml}$ + sulfamethoxazol $100 \mathrm{mg} / \mathrm{ml}$; Vetimex Animal Health BV, Cuyck, The Netherlands).

The experimental diets were fed for $18 \mathrm{~d}$ (3-21 d of age). Chicks were weighed individually and food consumption for each cage was recorded at the end of the trial. Water consumption was measured for each isolator separately during the collection period as the difference between a predetermined volume of water in the trough and the volume remaining in the trough.

\section{Digestibility}

In both trials digestibilities of the nutrients and ME were determined. This was done during the age period of 15 $19 \mathrm{~d}$. During this $4 \mathrm{~d}$ period the excreta were collected quantitatively according to the procedure described by Langhout et al. (1999). In the trial with conventional birds excreta were collected at $4 \mathrm{~h}$ intervals during the day (08.00-20.00 hours), and once for the night (20.00-08.00 hours). Day and night excreta were collected separately. Only the excreta collected during the day were used for analyses. In the trial with germ-free birds all excreta produced during the $4 \mathrm{~d}$ collection period were used for analyses. In both trials excreta were collected for each cage separately. In the trial with conventional chicks four cages per treatment were involved in the digestibility study, and in the trial with germ-free birds all isolators were used. The excreta were stored in closed containers at $-20^{\circ}$.

At the end of the trials, both diets and the excreta were analysed for DM, N, fat, starch, ash, amino acids and gross energy. In addition, the DM content of the night excreta was determined for calculating total DM output per $24 \mathrm{~h}$. The apparent ME of each diet was calculated from the values for gross energy of the food and excreta. The apparent ME values were corrected to zero $\mathrm{N}$ balance (apparent $\mathrm{ME}_{\mathrm{n}}$ ). The correction factor used was $34.39 \mathrm{~kJ} / \mathrm{g}$ retained $\mathrm{N}$ as proposed by Hill \& Anderson (1958).

Samples of feed and freeze-dried excreta were milled to pass through a $1.0 \mathrm{~mm}$ screen before analysis. All samples were taken in duplicate and analysed for the contents of $\mathrm{DM}$, inorganic matter, $\mathrm{N}$, gross energy, crude fat, starch and amino acids with the exception of tryptophan.

\section{Additional measurements}

After completion of the performance trial, fifteen randomly selected conventional birds per cage originating from the cages in which faecal digestibility of nutrients was also determined (sixty birds per treatment group) were used for determination of ileal digestibility. Food and water remained available to these birds until killing at $22 \mathrm{~d}$ of age, after which they were weighed individually. After killing through injection of $2 \mathrm{ml} /$ bird of T61 (Embutramide-Mebezoniumiodide-Tetracainhydrochloride mix; Hoechst, Munchen, Germany), samples were taken of the jejunum $100 \mathrm{~mm}$ preceding Meckel's diverticulum and of the ileum $100 \mathrm{~mm}$ preceding the ileo-caecal junction, for determination of jejunal and ileal digestibilities of energy and starch as described by Van der Klis et al. (1993). For analysis of the jejunal and ileal contents all fifteen samples per cage were pooled to give four replicate samples per treatment.

From all cages, four randomly selected conventional birds per cage (thirty-two birds per treatment group) as well as all germ-free birds (forty per treatment group) were used for additional measurements. Food and water remained available to these birds until killing at $22 \mathrm{~d}$ of age, after which they were weighed individually. After death through injection of T61 $(2 \mathrm{ml} / \mathrm{bird})$, the small intestine was removed immediately and the weight of the duodenum plus jejunum and ileum was recorded. In addition, caecal weight, including contents, was determined, and samples $30 \mathrm{~mm}$ long were taken from the intestinal wall, $150 \mathrm{~mm}$ distal to Meckel's diverticulum, for assessing morphological characteristics. For these measurements two birds per cage were taken. In addition, samples of the digesta of the duodenum plus jejunum and the ileum were taken for measuring viscosity and $\mathrm{pH}$. Furthermore, ileal digesta of the birds were analysed for lactic acid, formic acid and volatile fatty acids (VFA). The ileal digesta samples were taken from the proximal end of the duodenum to Meckel's diverticulum and from Meckel's diverticulum to the end of the small intestine. Analyses of the duodenum plus jejunum and ileal digesta were performed in pooled samples of four chicks each taken from a different cage or in one pooled sample per isolator.

\section{Analytical methods}

Chemical analysis. DM content was determined by drying the samples to a constant weight at $101^{\circ}$. Inorganic matter and $\mathrm{N}$ were determined by standard methods (Association of Official Analytical Chemists, 1984). Gross energy was determined with an IKA-C4000 adiabatic calorimeter. Crude fat was determined by treating feed or excreta for $1 \mathrm{~h}$ with $4 \mathrm{M}$ $\mathrm{HCl}$ and drying for $3 \mathrm{~h}$ under vacuum at $100^{\circ}$, followed by $8 \mathrm{~h}$ extraction with hexane according to EU 18.1.84 (European Union, 1984). Starch content was determined enzymically by hydrolysing the starch to glucose with amyloglucosidase according to the procedure NEN 3574 (Nederlands Normalisatie Instituut, 1992). Amino acids were determined by ionexchange chromatography (Slump, 1969) after hydrolysis of the samples with $6 \mathrm{M}-\mathrm{HCl}$ for $24 \mathrm{~h}$ at $100^{\circ}$. Methionine and cystine were determined by ion-exchange chromatography as methionine sulfate and cysteic acid respectively, after oxidation with performic acid (Moore, 1963).

Viscosity. The viscosity of the intestinal digesta was determined with a Brookfield digital viscometer (Model LVTD VCP-II, Brookfield Engineering Laboratories Inc., Stoughton, MA, USA) according to the method of Bedford \& Classen (1993).

$p H$. The $\mathrm{pH}$ of the aqueous fraction was measured in the same sample in which ileal viscosity was determined. The $\mathrm{pH}$ was measured by inserting a micro $\mathrm{pH}$ electrode (LoT 440-M3, Dr W. Ingold, Udorf, Germany) into the aqueous fraction.

Volatile fatty acids. Concentrations of lactic acid, formic acid and VFA (acetic, propionic, iso-butyric, butyric, isovaleric and valeric acids) of the ileal digesta were determined by GLC (model HP 5890, Hewlett, Palo Alto, CA, USA) according to the method of Langhout \& Schutte (1996). 
Morphological characteristics. Each sample of the small intestine was cut open longitudinally at the antimesenteric attachment. Samples were fixed on dental wax with the villi on the upper side and fixed in $0.1 \mathrm{M}$-phosphate-buffered formalin solution $(40 \mathrm{ml} / \mathrm{l})$. The shape of the villi was studied with a dissecting microscope and characterized as described previously (Langhout et al. 1998). The following classes of villi were distinguished: tongue-shaped, fingershaped, leaf-shaped, ridge-shaped and convoluted villi.

\section{Statistical analysis}

Data were subjected to ANOVA with the SPSS/PC + V5.0 computer program of Norusis (1992). Treatment factors were type of diet and battery tier for the trial with conventional chicks, and type of diet and sub-trial for the trial with germ-free chicks. The treatment means were tested for difference by using the least significant difference test (Snedecor \& Cochran, 1980). All statements of significance are based on a probability of less than 0.05.

Weight gain, food intake, food conversion efficiency, water consumption, faecal digestibility of nutrients, $\mathrm{N}$ retention, ME content, weights of the small intestine and caecum, $\mathrm{pH}$ and viscosity of the ileal digesta for the germ-free birds in both sub-trials were similar and not statistically different. This indicates that the slight contamination of the birds with $B$. lichenifermis in the second sub-trial did not interfere with the results of the trial.

\section{Results}

The mortality rate was low as only $1.5 \%$ of the conventional birds and $1.7 \%$ of the germ-free birds died. The performance data for both trials are summarized in Table 2. In

Table 2. Effect of highly methylated citrus pectin (HMC) on performance in conventional (1-21 d of age) and germ-free (3-21 d of age) chicks*

(Mean values with their pooled standard errors for six (conventional) or four (germ-free) replicate cages per treatment group)

\begin{tabular}{|c|c|c|c|}
\hline & \multicolumn{2}{|c|}{ Dietary treatment } & \multirow[b]{3}{*}{ SEM } \\
\hline & & Maize $+30 \mathrm{~g}$ & \\
\hline & Maize & $\mathrm{HMC} / \mathrm{kg}$ & \\
\hline \multicolumn{3}{|l|}{ Conventional chicks } & (d.f. 13) \\
\hline Weight gain $(\mathrm{g})$ & $773^{b}$ & $696^{\mathrm{a}}$ & $6 \cdot 4$ \\
\hline Food intake ( $\mathrm{g} / \mathrm{d}$ per bird) & $48 \cdot 8^{a}$ & $50 \cdot 9^{b}$ & 0.29 \\
\hline Food utilization (MJ/kg gain) & $17.04^{\mathrm{a}}$ & $19 \cdot 73^{b}$ & 0.102 \\
\hline Water intake $(\mathrm{g} / \mathrm{d} \text { per bird })^{\dagger^{\prime}}$ & $139^{\mathrm{a}}$ & $181^{\mathrm{b}}$ & $2 \cdot 7$ \\
\hline Water: food $\dagger$ & $1.83^{a}$ & $2 \cdot 32^{b}$ & 0.028 \\
\hline \multicolumn{3}{|l|}{ Germ-free chicks } & (d.f. 5) \\
\hline Weight gain $(\mathrm{g})$ & $737^{b}$ & $694^{\mathrm{a}}$ & 11.2 \\
\hline Food intake (g/d per bird) & $51 \cdot 1$ & 49.5 & 0.80 \\
\hline Food utilization (MJ/kg gain) & 16.95 & 17.44 & 0.152 \\
\hline Water intake (g/d per bird) $\dagger$ & 154 & 154 & 4.7 \\
\hline Water:foodt & $2.03^{a}$ & $2 \cdot 28^{b}$ & 0.066 \\
\hline
\end{tabular}

\footnotetext{
a,b Mean values within a row and type of chick not sharing a common superscript letter were significantly different: $P<0.05$.

* For details of diets and procedures, see Table 1 and pp. 534-536.

† Means of $4 \mathrm{~d}$ (age period 17-21d).
}

Table 3. Effect of highly methylated citrus pectin (HMC) on jejunal and ileal digestibility coefficients of starch and energy in conventional chicks*

(Mean values with their pooled standard errors for four replicate cages per treatment group)

\begin{tabular}{|c|c|c|c|}
\hline & \multicolumn{2}{|c|}{ Dietary treatment } & \multirow[b]{2}{*}{$\begin{array}{l}\text { SEM } \\
\text { (d.f. 5) }\end{array}$} \\
\hline & Maize & $\begin{array}{c}\text { Maize }+30 \mathrm{~g} \\
\mathrm{HMC} / \mathrm{kg}\end{array}$ & \\
\hline \multicolumn{4}{|c|}{ Digestibility at the end of the jejunum } \\
\hline energy & $65 \cdot 2^{a}$ & $51 \cdot 5^{b}$ & $1 \cdot 81$ \\
\hline starch & $89.4^{a}$ & $82.9^{b}$ & 1.41 \\
\hline \multicolumn{4}{|c|}{ Digestibility at the end of the ileum } \\
\hline energy & $72 \cdot 5^{\mathrm{a}}$ & $65 \cdot 2^{b}$ & 0.78 \\
\hline starch & $95 \cdot 6^{\mathrm{a}}$ & $92 \cdot 6^{\mathrm{b}}$ & 0.44 \\
\hline
\end{tabular}

${ }^{a, b}$ Mean values within a row not sharing a common superscript letter were significantly different: $P<0.05$.

*For details of diets and procedures, see Table 1 and pp. 534-536.

both trials, treatment groups did not differ appreciably in mortality rate. Feeding the HMC diet to conventional chicks depressed weight gain and food utilization by $9.5 \%$ and $15.2 \%$ respectively. In germ-free chicks fed on the HMC diet only, weight gain was reduced significantly by $5.8 \%$, whereas food utilization decreased only slightly $(P>0 \cdot 05)$. Feeding the HMC diet to conventional birds resulted in an increased water intake and water: food value $(P<0.05)$. Feeding these diets to germ-free birds resulted in an elevated water: food value $(P<0 \cdot 05)$.

Feeding the HMC diet to conventional chicks reduced digestibilities of energy and starch at the end of the jejunum (Table 3). At the end of the ileum, digestibilities of energy and starch were reduced to a lesser extent by including $\mathrm{HMC}$ in the diet.

Table 4. Effect of highly methylated citrus pectin (HMC) on faecal digestibility, $\mathrm{N}$ retention and metabolizable energy in conventional and germ-free chicks*

(Mean values with their pooled standard errors for four replicate cages per treatment group)

\begin{tabular}{|c|c|c|c|}
\hline & \multicolumn{2}{|c|}{ Dietary treatment } & \multirow[b]{2}{*}{$\begin{array}{l}\text { SEM } \\
\text { (d.f. 5) }\end{array}$} \\
\hline & Maize & $\begin{array}{c}\text { Maize }+30 \mathrm{~g} \\
\mathrm{HMC} / \mathrm{kg}\end{array}$ & \\
\hline \multicolumn{4}{|l|}{ Conventional chicks } \\
\hline DM & $71.6^{b}$ & $64 \cdot 8^{a}$ & 0.25 \\
\hline organic matter & $73 \cdot 3^{b}$ & $68 \cdot 8^{a}$ & 0.26 \\
\hline crude fat & $81 \cdot 3^{b}$ & $65 \cdot 7^{\mathrm{a}}$ & 0.66 \\
\hline starch & $96 \cdot 9^{b}$ & $95 \cdot 3^{a}$ & 0.11 \\
\hline $\mathrm{N}$ retention (\% intake) & $56 \cdot 9^{b}$ & $51.9^{a}$ & 0.33 \\
\hline Metabolizable energy† (MJ/kg) & $13 \cdot 32^{b}$ & $11.81^{\mathrm{a}}$ & 0.071 \\
\hline \multicolumn{4}{|l|}{ Germ-free chicks } \\
\hline DM & 74.4 & 74.6 & 0.70 \\
\hline organic matter & $76 \cdot 7$ & $76 \cdot 4$ & 0.65 \\
\hline crude fat & 93.9 & 94.8 & 0.32 \\
\hline starch & 98.9 & 98.9 & 0.15 \\
\hline $\mathrm{N}$ retention (\% intake) & $62 \cdot 4$ & $63 \cdot 6$ & 1.24 \\
\hline Metabolizable energy† (MJ/kg) & $13 \cdot 76^{\mathrm{a}}$ & $14 \cdot 26^{\mathrm{b}}$ & 0.095 \\
\hline
\end{tabular}

\footnotetext{
${ }^{a, b}$ Mean values within a row and type of chick not sharing a common superscript letter were significantly different: $P<0.05$.

* For details of diets and procedures, see Table 1 and pp. 534-536.

† Corrected to zero $\mathrm{N}$ balance.
} 
Table 5. Effect of highly methylated citrus pectin (HMC) on faecal amino acid digestibility in conventional and germ-free chicks*

(Mean values with their pooled standard errors for four replicate cages per treatment group)

\begin{tabular}{|c|c|c|c|}
\hline & \multicolumn{2}{|c|}{ Dietary treatment } & \multirow[b]{2}{*}{$\begin{array}{l}\text { SEM } \\
\text { (d.f. 5) }\end{array}$} \\
\hline & Maize & $\begin{array}{c}\text { Maize }+30 \mathrm{~g} \\
\mathrm{HMC} / \mathrm{kg}\end{array}$ & \\
\hline \multicolumn{4}{|l|}{ Conventional chicks } \\
\hline Isoleucine & $88 \cdot 2^{b}$ & $76 \cdot 5^{a}$ & 0.19 \\
\hline Leucine & $89.7^{\mathrm{b}}$ & $77 \cdot 4^{a}$ & 0.24 \\
\hline Lysine & $89 \cdot 7^{\mathrm{b}}$ & $80 \cdot 1^{\mathrm{a}}$ & 0.24 \\
\hline Methionine & $92 \cdot 1^{\mathrm{b}}$ & $82 \cdot 2^{\mathrm{a}}$ & 0.20 \\
\hline Cystine & $70 \cdot 9^{b}$ & $53.4^{\mathrm{a}}$ & 0.25 \\
\hline Methionine + cystine & $84.5^{\mathrm{b}}$ & $72 \cdot 1^{\mathrm{a}}$ & 0.21 \\
\hline Threonine & $82 \cdot 5^{\mathrm{b}}$ & $68 \cdot 7^{a}$ & 0.20 \\
\hline Valine & $87 \cdot 3^{\mathrm{b}}$ & $75 \cdot 3^{a}$ & 0.21 \\
\hline Arginine & $91 \cdot 7^{\mathrm{b}}$ & $81 \cdot 7^{\mathrm{a}}$ & 0.13 \\
\hline Alanine & $84 \cdot 2^{b}$ & $70 \cdot 5^{a}$ & 0.29 \\
\hline Aspartic acid & $86 \cdot 0^{\mathrm{b}}$ & $78 \cdot 8^{a}$ & 0.28 \\
\hline Glutamic acid & $90 \cdot 9^{b}$ & $81 \cdot 3^{\mathrm{a}}$ & 0.14 \\
\hline Glycine & $77 \cdot 8^{\mathrm{b}}$ & $64 \cdot 1^{\mathrm{a}}$ & 0.16 \\
\hline Serine & $86 \cdot 2^{b}$ & $74 \cdot 2^{a}$ & 0.20 \\
\hline Mean amino acids & $85 \cdot 9$ & $73 \cdot 8$ & - \\
\hline \multicolumn{4}{|l|}{ Germ-free chicks } \\
\hline Isoleucine & $92 \cdot 8$ & $92 \cdot 8$ & 0.25 \\
\hline Leucine & $94 \cdot 1$ & $94 \cdot 2$ & 0.22 \\
\hline Lysine & $91 \cdot 0$ & 91.6 & 0.28 \\
\hline Methionine & $94 \cdot 3$ & 94.4 & 0.24 \\
\hline Cystine & $70 \cdot 2$ & 69.4 & 0.60 \\
\hline Methionine + cystine & $86 \cdot 2$ & $85 \cdot 3$ & 0.31 \\
\hline Threonine & 87.6 & $87 \cdot 3$ & 0.30 \\
\hline Valine & $92 \cdot 0$ & 92.5 & 0.27 \\
\hline Arginine & 93.3 & 93.5 & 0.22 \\
\hline Alanine & 90.4 & $90 \cdot 7$ & 0.27 \\
\hline Aspartic acid & 88.9 & $89 \cdot 1$ & 0.31 \\
\hline Glutamic acid & 93.4 & 93.4 & 0.21 \\
\hline Glycine & $82 \cdot 4$ & $82 \cdot 6$ & 0.48 \\
\hline Serine & 89.1 & 88.8 & 0.31 \\
\hline Mean amino acids & 91.2 & $91 \cdot 1$ & - \\
\hline
\end{tabular}

${ }_{a, b}$ Mean values within a row and type of chick not sharing a common superscript letter were significantly different: $P<0.05$.

* For details of diets and procedures, see Table 1 and pp. 534-536.

HMC significantly reduced faecal digestibilities of DM, organic matter, starch and crude fat, $\mathrm{N}$ retention and $\mathrm{ME}$ value of the diet in conventional chicks (Table 4). Feeding the HMC diet to germ-free chicks, however, had hardly any effect on faecal digestibilities of DM, organic matter, starch and crude fat or on $\mathrm{N}$ retention $(P>0.05)$, whereas that diet's ME value increased $(P<0 \cdot 05$; Table 4$)$. Digestibility of amino acids was significantly depressed when HMC was added to the diet of conventional chicks (Table 5). Digestibility of the individual amino acids declined between 17.5 and $7.2 \%$ in the conventional chicks fed on the HMC diet. In germ-free chicks hardly any effect on the digestibility of amino acids was found.

Feeding the HMC diet to conventional chicks increased viscosity of digesta in the proximal part of the small intestine compared with birds fed on the control diet $(P<$ 0.05; Table 6). Digesta of the ileum content of birds fed on the HMC diet was gel-like and had a high water-binding capacity. Digesta viscosity of birds fed on this diet could not be measured as no supernatant fraction was obtained after centrifugation of the digesta $\left(10000 \mathrm{~g}\right.$ for $10 \mathrm{~min}$ at $\left.4^{\circ}\right)$, but
Table 6. Effect of highly methylated citrus pectin (HMC) on digesta viscosity and $\mathrm{pH}$ of the proximal and distal part of the small intestine and on the weights of the small intestine and caecum of conventional and germ-free chicks at $22 \mathrm{~d}$ of age*

(Mean values with their pooled standard errors for six (conventional) or four (germ-free) replicate cages per treatment group)

\begin{tabular}{|c|c|c|c|}
\hline & Dietar & treatment & \\
\hline & & Maize $+30 \mathrm{~g}$ & \\
\hline & Maize & $\mathrm{HMC} / \mathrm{kg}$ & SEM \\
\hline Conventional chicks & & & $\overline{\text { (d.f. 13) }}$ \\
\hline Digesta viscosity (mPa.s) & & & \\
\hline Duodenum + jejunum & $1 \cdot 7^{\mathrm{a}}$ & $60 \cdot 8^{b}$ & 0.35 \\
\hline lleum & $2 \cdot 4$ & n.m. & \\
\hline $\mathrm{pH}$ & & & \\
\hline Duodenum + jejunum & $5 \cdot 3$ & $5 \cdot 2$ & 0.14 \\
\hline Ileum & $6 \cdot 6^{\mathrm{a}}$ & $5 \cdot 5^{b}$ & 0.184 \\
\hline $\begin{array}{l}\text { Weight (including content } \\
\text { (g/kg body wt) }\end{array}$ & & & \\
\hline Duodenum + jejunum & $46^{\mathrm{a}}$ & $58^{b}$ & 0.9 \\
\hline lleum & $20^{a}$ & $30^{\mathrm{b}}$ & 0.6 \\
\hline Total small intestine & $66^{\mathrm{a}}$ & $88^{\mathrm{b}}$ & 1.3 \\
\hline Caecum & 7.9 & 8.9 & 0.4 \\
\hline Germ-free chicks & & & (d.f. 5) \\
\hline Digesta viscosity (mPa.s) & & & \\
\hline Duodenum + jejunum & $2 \cdot 2^{\mathrm{a}}$ & $7 \cdot 3^{b}$ & 0.39 \\
\hline lleum & $2 \cdot 8^{a}$ & $12 \cdot 4^{\mathrm{b}}$ & 1.15 \\
\hline $\mathrm{pH}$ & & & \\
\hline Duodenum + jejunum & $6 \cdot 6$ & 6.5 & 0.054 \\
\hline lleum & 7.9 & $7 \cdot 8$ & 0.029 \\
\hline Weight (including content & & & \\
\hline (g/kg body wt) & & & \\
\hline Duodenum + jejunum & 33 & 35 & 1.4 \\
\hline Ileum & 16 & 19 & 1.0 \\
\hline Total small intestine & 49 & 53 & $2 \cdot 3$ \\
\hline Caecum & $8 \cdot 1^{\mathrm{a}}$ & $16 \cdot 2^{b}$ & 1.22 \\
\hline
\end{tabular}

n.m., not measurable.

a,b Mean values within a row and type of chick not sharing a common superscript letter were significantly different: $P<0.05$.

${ }^{*}$ For details of diets and procedures, see Table 1 and pp. 534-536.

was certainly very high. In germ-free chicks, viscosity of digesta in the proximal and the distal part of the small intestine was also elevated when HMC was included in the diet. However, the magnitude of the increase in digesta viscosity was markedly lower than in conventional chicks. Feeding the HMC diet to conventional chicks had little effect on digesta $\mathrm{pH}$ in the proximal part of the small intestine, whereas the $\mathrm{pH}$ of the ileal digesta was reduced significantly (Table 6). Feeding the HMC diet to germ-free chicks had little effect on the $\mathrm{pH}$ of digesta in the different parts of the small intestine. In germ-free birds higher values were found in the proximal and distal parts of the small intestine than in conventional birds. In conventional birds fed on the HMC diet, weights of the duodenum plus jejunum and of the ileum were higher than in birds fed on the control diet (Table 6). Caecal weights tended to be higher in conventional birds fed on the HMC-based diet $(P>0.05)$. The inclusion of HMC in the diet of germ-free chicks hardly affected the weights of the different parts of the small intestine, whereas caecal weights were increased significantly.

Feeding the HMC diet to conventional chicks increased the concentration of lactic acid in ileal digesta $(P<0.05$; 
Table 7. Effect of highly methylated citrus pectin (HMC) on the concentrations of lactic acid, formic acid and volatile fatty acids (VFA) in the ileal digesta $(\mathrm{mg} / \mathrm{kg})$ of conventional chicks at $22 \mathrm{~d}$ of age* (Mean values with their pooled standard errors for six replicate cages per treatment group)

\begin{tabular}{llcc}
\hline & \multicolumn{2}{c}{ Dietary treatment } \\
\cline { 2 - 3 } & Maize & $\begin{array}{c}\text { Maize }+30 \mathrm{~g} \\
\text { HMC } / \mathrm{kg}\end{array}$ & $\begin{array}{c}\text { SEM } \\
\text { (d.f. 13) }\end{array}$ \\
\hline Lactic acid & $1.57^{\mathrm{a}}$ & $2.13^{\mathrm{b}}$ & 0.145 \\
Formic acid & 0.16 & 0.15 & 0.027 \\
Total VFA & 0.33 & 0.42 & 0.121 \\
Acetic acid & 0.06 & 0.14 & 0.105 \\
Propionic acid & 0.11 & 0.12 & 0.020 \\
Iso-butyric acid & $0.08^{\mathrm{a}}$ & $0.02^{\mathrm{b}}$ & 0.014 \\
Butyric acid & 0.01 & 0.05 & 0.017 \\
Iso-valeric acid & 0.05 & 0.06 & 0.021 \\
Valeric acid & 0.03 & 0.03 & 0.017 \\
\hline a,b Mean values within a row not sharing a common superscript letter were \\
significantly different: $P<0.05$.
\end{tabular}

Table 7). The concentration of VFA in the ileal digesta was hardly affected by HMC. In the digesta of the germ-free chicks no lactic acid, formic acid or VFA could be detected. These results indicate also the absence of microbial activity in the intestinal tract of the germ-free chicks.

Feeding the HMC diet to conventional chicks affected the classification and the shape of the villi (Table 8). The number of zigzag patterns and ridge-shaped villi was reduced in conventional birds fed on the HMC diet compared with those present in birds fed on the control diet, whereas the number of tongue-shaped villi was higher. No significant change in classification and shape of the villi was

Table 8. Effect of highly methylated citrus pectin (HMC) on classification and shape of the villi in the ileum of 22-d-old conventional and germ-free chicks*

(Mean values with their pooled standard errors for six (conventional) or four (germ-free) replicate cages per treatment group)

\begin{tabular}{|c|c|c|c|}
\hline & \multicolumn{2}{|c|}{ Dietary treatment } & \multirow[b]{3}{*}{ SEM } \\
\hline & & Maize $+30 \mathrm{~g}$ & \\
\hline & Maize & $\mathrm{HMC} / \mathrm{kg}$ & \\
\hline \multicolumn{3}{|l|}{ Conventional chicks } & (d.f. 13) \\
\hline \multicolumn{4}{|l|}{ Classification of the villi (\% total) } \\
\hline Zigzag & $61^{a}$ & $7^{\mathrm{b}}$ & $19 \cdot 3$ \\
\hline \multicolumn{4}{|l|}{ Shape of the villi (\% total) } \\
\hline Tongue-shaped & $23^{a}$ & $53^{b}$ & 18.5 \\
\hline Leaf-shaped & 36 & 42 & $17 \cdot 3$ \\
\hline Ridge-shaped & $36^{a}$ & $1^{\mathrm{b}}$ & $16 \cdot 9$ \\
\hline Convoluted & 5 & 4 & $4 \cdot 4$ \\
\hline \multicolumn{3}{|l|}{ Germ-free chicks } & (d.f. 5) \\
\hline \multicolumn{4}{|l|}{ Classification of the villi (\% total) } \\
\hline Zigzag & 31 & 43 & $9 \cdot 1$ \\
\hline \multicolumn{4}{|l|}{ Shape of the villi (\% total) } \\
\hline Tongue-shaped & 33 & 32 & $6 \cdot 5$ \\
\hline Leaf-shaped & 39 & 43 & $3 \cdot 1$ \\
\hline Ridge-shaped & 24 & 24 & $5 \cdot 8$ \\
\hline Convoluted & 4 & 1 & 1.8 \\
\hline
\end{tabular}

\footnotetext{
${ }^{a, b}$ Mean values within a row and type of chick not sharing a common superscript letter were significantly different: $P<0.05$.

* For details of diets and procedures, see Table 1 and pp. 534-536.
}

observed when HMC was included in the diet of germ-free chicks.

\section{Discussion}

In the germ-free chicks study, diets were sterilized by $\gamma$-irradiation whereas the diets fed to the conventional chicks were not. This treatment might interfere with the anti-nutritive effects of HMC. It has been reported that $\gamma$-irradiation increases the nutritional value of rye and barley for chicks (MacAuliffe et al. 1979; Patel et al. 1980; Campbell et al. 1983b, 1986) but not that of wheat and triticale (Campbell et al. 1986). The improvement noted for rye and barley, which is mainly manifested by increased food utilization and apparent absorption of fat, is thought to be due to depolymerization of the soluble pentosans (Campbell et al. $1983 b)$ and $\beta$-glucans (Classen et al. 1985), respectively. Patel et al. (1980) studied the effect of non-irradiated and irradiated citrus pectin at dose levels of 33 and $40 \mathrm{~g} / \mathrm{kg}$ in young chicks by using a maize-soyabean diet. They reported a significant improvement in weight gain and food utilization with $\gamma$-irradiation of citrus pectin. Campbell et al. (1983a) studied the effect of the utilization of rye in chicks in relation to the microbial status and $\gamma$-irradiation. These investigators reported that by feeding irradiated rye diets, fat retention of germ-free chicks was superior to that of conventional chicks $(70.1$ v. $52.7 \%)$. In addition, higher values for amino acid digestibility were found in germ-free than in conventional chicks when feeding irradiated rye diets. From the reports cited here it can be concluded that $\gamma$-irradiation benefits chicks fed on diets containing rye, barley or citrus pectin, and therefore, might have influenced the magnitude of the differences in results between the germ-free and conventional chicks in the present study. Nevertheless, considering the results of Campbell et al. (1983a), it might be assumed that the differences in results between the germ-free and conventional chicks fed on the HMC diets in the present study may be attributed to a considerable extent to the microbial status of the chicks.

The results of the present study show that dietary addition of HMC reduces performance of conventional broiler chicks. These results agree well with those obtained in previous studies (Langhout \& Schutte, 1996; Langhout et al. 1998, 1999). The reduction in performance of conventional birds fed on HMC was at least partly due to a decrease in nutrient digestibility. The inclusion of HMC in the diet of germ-free chicks had only limited anti-nutritive effects on performance and nutrient digestibility compared with those observed in conventional chicks. Thus, our results indicate that the gastrointestinal microflora plays an important role in the magnitude of the anti-nutritive effects of water-soluble NSP in broiler chicks. Similar findings have been reported for rye by Campbell et al. (1983a) who also showed that the decrease in performance was more pronounced in conventional chicks than in germfree chicks.

The results of the present study show that inclusion of $\mathrm{HMC}$ in the diet of germ-free birds increased the ME of the diet. This increase in energy content of the diet might be the result of the slight but non-significant improvement in protein and fat digestibility in chicks fed on the HMC diet. 
It is generally assumed that the viscous properties of watersoluble NSP are mainly responsible for the anti-nutritive effects in broiler chicks. In germ-free chicks the increase in digesta viscosity caused by diets containing HMC was considerably lower than in conventional chicks fed on the same diets. The effects of HMC on the water: food value were similar in conventional and germ-free birds. Therefore, the difference in digesta viscosity between germ-free and conventional chicks fed on the HMC-based diets could not be explained by a difference in water consumption. Since HMC is readily fermented by the intestinal microbes (McBurney et al. 1985) it cannot be excluded that HMC is partly fermented into smaller fractions. As a result, ileal viscosity will increase, which in turn may impair diffusion of pancreatic enzymes within the ileal contents (Edwards et al. 1988). Moreover, transport and mixing of digestive enzymes and nutrients may be limited, which reduces hydrolysis of nutrients by digestive enzymes (Fengler \& Marquardt, 1988). This may slow down the digestion of nutrients in the proximal part of the small intestine. This notion is supported by the results of the present study, in which less energy and starch were digested at the end of the jejunum in conventional chicks fed on the HMC diet than in chicks fed on the maize diet. The increase in undigested nutrients in the lower part of the intestinal tract may promote microbial growth.

In the present study, dietary inclusion of HMC in the diet of conventional chicks was associated with an increase in concentration of lactic acid and a decrease in $\mathrm{pH}$ in the ileal digesta. Both effects are associated with an increased microbial activity in the small intestine of chicks fed on a diet containing HMC. Others have shown that microbial activity increases in the ileum when birds are fed on diets containing rye (Wagner \& Thomas, 1978; Langhout et al. 1999), wheat (Choct et al. 1996) or HMC (Wagner \& Thomas, 1978; Langhout et al. 1998, 1999). The results of the present study show that ileal digestibility of starch was slightly influenced when HMC was included in the diet. This indicates that the increase in microbial activity could only partly be the result of an increase in fermentation of starch. Therefore, it is most likely that fermentation of the HMC fraction was mainly responsible for the increase in microbial activity.

The effect of elevated microbial activity in the small intestine on nutrient utilization is still not well understood. An increase in microbial activity in the small-intestinal tract indicates that more nutrients are fermented instead of enzymically hydrolysed and digested. The end-products of microbial degradation of carbohydrates are lactic acid, formic acid and VFA. Pigs can utilize these end-products as an energy source, albeit with a lower efficiency than glucose, for example. In pigs, the losses are reported to vary between 33\% (Agricultural Research Council, 1981) and $50 \%$ (Just et al. 1983; Van Es, 1974). For poultry no published results are available. However, it may be assumed that these losses are of similar magnitude as in pigs. Moreover, bacteria are able to incorporate amino acids into microbial protein (Salter \& Coates, 1974). This may explain the lower $\mathrm{N}$ utilization in conventional birds compared with germ-free birds as shown in the present study and by Furuse \& Yokota (1985). In addition, many bacterial species are able to deconjugate bile acids (Hylemond, 1985). Therefore, an increase in microbial activity in the intestinal tract may increase bile acid deconjugation. This is supported by the results of Langhout et al. (1999), who showed an increase in concentration of unconjugated bile acids in birds fed on diets containing HMC or rye and wheat. Deconjugated bile acids may impair micelle formation and consequently reduce digestion of fat, particularly of fats containing long-chain saturated fatty acids (Garrett \& Young, 1975).

The results of the present study show that addition of HMC to the diet of conventional chicks affects morphology of the villi in the ileum. These results agree with those obtained in a previous study (Langhout et al. 1999). This change in gut morphology may have reduced nutrient absorption. In germ-free birds, HMC had little effect on the morphology of the villi. Gee et al. (1996) concluded that the effect of gelling agents on mucosal conditions is dependent on their fermentability. Such products as amines, $\mathrm{NH}_{3}$ and toxins, produced by the intestinal microflora, have been suggested to have deleterious effects on the gut wall. Therefore, it can be speculated that a change in metabolic activity of the intestinal microflora affects gut morphology.

Based on the results of the present study, it can be concluded that the gastrointestinal microflora mediates the magnitude of the anti-nutritive effects of HMC in broiler chicks by affecting viscous properties and fermentation of HMC in the gastrointestinal tract. However, the exact role of the microflora in chicks on the magnitude of the antinutritive effects of HMC cannot be derived from the present study, since these results might have been influenced by $\gamma$-irradiation of the germ-free chick diets.

\section{Acknowledgements}

The authors wish to thank G. M. Beelen, A. J. M. A. Verstraten and $\mathrm{H}$. van Zoelen for technical support and R. O. M. Coolen and J. M. J. van den Driessche for chemical analysis.

\section{References}

Agricultural Research Council (1981) The Nutrient Requirement of Pigs. Slough: Commonwealth Agricultural Bureaux.

Antoniou T \& Marquardt RR (1982) Utilization of rye diets by chicks as affected by lipid type and level and penicillin supplementation. Poultry Science 61, 107-116.

Antoniou T, Marquardt RR \& Cansfield PS (1981) Isolation, partial characterization and antinutritional activity of a factor (pentosans) in rye grain. Journal of Agricultural and Food Chemistry 28, 1240-1247.

Association of Official Analytical Chemists (1984) Official Methods of Analysis, 14th ed. Washington, DC: AOAC.

Bedford MR \& Classen HL (1993) An in vitro assay for prediction of broiler intestinal viscosity and growth when fed rye-based diets in the presence of exogenous enzymes. Poultry Science $\mathbf{7 2}$, 137-143.

Campbell GL, Campbell LD \& Classen HL (1983a) Utilisation of rye by chickens; effect of microbial status, diet gamma irradiation and sodium taurocholate supplementation. British Poultry Science 24, 191-203.

Campbell GL, Classen HL \& Ballange GM (1986) Gamma irradiation treatment of cereal grains for chick diets. Journal of Nutrition 116, 560-569. 
Campbell GL, Classen HL, Reichert RD \& Campbell LD (1983b) Improvement of the nutritive value of rye for broiler chickens by gamma irradiation-induced viscosity reduction. British Poultry Science 24, 205-212.

Choct M \& Annison G (1990) Anti-nutritive activity of wheat pentosans in broiler diets. British Poultry Science 31, 811-821.

Choct M \& Annison G (1992) The inhibition of nutrient digestion by wheat pentosans. British Journal of Nutrition 67, 123-132.

Choct M, Hughes RJ, Wang J, Bedford MR, Morgan AJ \& Annison G (1996) Increased small intestinal fermentation is partly responsible for the anti-nutritive activity of non-starch polysaccharides in chickens. British Poultry Science 37, 609-621.

Classen HL, Campbell GL, Rosnagel BG, Bhatty R \& Reichert RD (1985) Studies on the use of hulles barley in chick diets: deleterious effects and methods of alleviation. Canadian Journal of Animal Science 65, 725-733.

Coates ME, Cole CB, Fuller R, Houghton SB \& Yokota H (1981) The gut microflora and the uptake of glucose from the small intestine of the chick. British Poultry Science 22, 289-294.

Dutch Bureau of Livestock Feedingstuffs (1994) Chemical Composition, Digestibility and Energy Value of Feed Ingredients. Lelystad, The Netherlands: Bureau of Livestock Feedingstuffs.

Edwards CA, Johnson II \& Read NW (1988) Do viscous polysaccharides slow absorption by inhibiting diffusion or convection? European Journal of Clinical Nutrition 42, 307-312.

European Union (1984) Determination of crude oils and fats. Official Journal of the European Communities EU 18.1.84 no. 15/29-30.

Fengler AI \& Marquardt RR (1988) Water-soluble pentosans from rye: II. Effects on rate of dialysis and on the retention of nutrients by the chick. Cereal Chemistry 65, 298-302.

Furuse M \& Yokota H (1985) Effect of the gut microflora on chick growth and utilization of protein and energy at different concentrations of dietary protein. British Poultry Science 26, 97104.

Garrett RL \& Young RJ (1975) Effect of micelle formation on the absorption of neutral fat and fatty acids by the chicken. Journal of Nutrition 105, 827-838.

Gee JM, Lee-Finglas W, Wortley GW \& Johnson IT (1996) Fermentable carbohydrates elevate plasma enteroglucagon but high viscosity is also necessary to stimulate small bowel mucosal cell proliferation in rats. Journal of Nutrition 126, 373-379.

Hill FW \& Anderson DL (1958) Comparison of metabolizable energy and productive energy determinations with growing chicks. Journal of Nutrition 64, 587-603.

Hylemond PB (1985) Metabolism of bile acids in intestinal microflora. In Sterols and Bile Acids: New Comprehensive Biochemistry, pp. 331-343 [H Danielsen and J Sjövall, editors]. Amsterdam: Elsevier Science Publishers B.V.

Just A, Fernande JA \& Jorgensen H (1983) The net energy value of diets for growth in pigs in relation to the fermentative processes in the digestive tract and the site of absorption of the nutrients. Livestock Production Science 10, 171-186.

Langhout DJ \& Schutte JB (1996) Nutritional implications of pectins in chicks in relation to esterification and origin of pectins. Poultry Science 75, 1236-1242.
Langhout DJ, Schutte JB, Tangerman A, Verstraten AJMA, Van Schaik A \& Beelen G (1999) Effect of dietary viscous polysaccharides on the ileal microflora and on bile acid deconjugation in broiler chicks. British Poultry Science (In the Press).

Langhout DJ, Schutte JB, Van Leeuwen P, Wiebenga J \& Tamminga S (1998) Effect of dietary high- and low-methylated citrus pectin on activity of the ileal microflora and morphology of the small intestinal wall of broiler chicks. British Poultry Science 40, 340-347.

MacAuliffe T, Zaviezo D \& Bayley HS (1979) Effect of gamma irradiation, fractionation, and penicillin supplementation on the rachitogenic activity of rye for chicks. Poultry Science 58, 329332.

McBurney MI, Horvath PJ, Jeraci LJ \& Van Soest PJ (1985) Effect of in vitro fermentation using human faecal inoculum on the water-holding capacity of dietary fibre. British Journal of Nutrition 53, 17-24.

Moore S (1963) On the determination of cysteic as cystic acid. Journal of Biology and Chemistry 238, 235-237.

National Research Council (1994) Nutrient Requirements of Poultry, 9th revised ed. Washington DC: National Academy of Sciences.

Nederlands Normalisatie Instituut (1992) NNI-catalogus I. Delft, The Netherlands: NNI.

Norusis MJ (1992) SPSS/PC+ Base System User's Guide, version 5.0. Chicago, IL: SPSS Inc.

Patel MB, Jami MS \& McGinnis J (1980) Effect of gamma irradiation, penicillin, and/or pectic enzyme on chick growth depression and fecal stickiness caused by rye, citrus pectin, and guar gum. Poultry Science 59, 2105-2110.

Salter DN \& Coates ME (1974) The utilization of protein and excretion of uric acid in germ-free and conventional chicks. British Journal of Nutrition 31, 307-318.

Slump P (1969) Characterization of nutritive value of food protein by amino acid composition. PhD Thesis, Free University of Amsterdam.

Snedecor GW \& Cochran WG (1980) Statistical Methods, 7th ed. Ames, IA: The Iowa State University Press.

Van Es AJH (1974) Energy utilization of low digestibility carbohydrates. In Low Digestibility Carbohydrates, pp. 121-127 [DC Leegwater, VJ Feron and RJJ Hermus, editors]. Wageningen: Pudoc Press.

Van der Klis JD, Verstegen MWA \& Van Voorst A (1993) Effect of a soluble polysaccharide (Carboxy Methyl Cellulose) on the absorption of minerals from the gastrointestinal tract of broilers. British Poultry Science 34, 377-389.

Wagner DD \& Thomas OP (1978) Influence of diets containing rye or pectin on the intestinal flora of chicks. Poultry Science 57, 971-975.

Ward AT \& Marquardt RR (1983) The effect of saturation, chain length of pure triglycerides, and age of bird on the utilization of rye diets. Poultry Science 62, 1054-1062.

White WB, Bird HR, Sunde ML, Prentice N, Burger WC \& Marlett JA (1981) The viscosity interaction of barley $\beta$-glucan with Trichoderma viride cellulase in the chick intestine. Poultry Science 62, 853-862. 